\title{
PENGARUH GENDER, TEKANAN KETAATAN,PENGETAHUAN, KEAHLIAN, DAN PENGALAMAN TERHADAP KUALITAS AUDIT STUDI PADA INSPEKTORAT PROVINSI DIY
}

\author{
Felia Nawang Wulan \\ Arif Sapta Yuniarto
}

\begin{abstract}
This study examines the influence of gender, compliance pressure, audit knowledge, expertise, and auditor experience to audit quality. The respondents in this study were auditors who worked in The Inspectorate of DIY. The number of auditor who observed in this study was 40 auditors. They came from some auditors who worked in The Inspectorate of DIY. The method of determining the sample was purposive sampling method, the data processing methods that used by researcher were the multiple regression analysis. The result shows that the gender,compliance pressure, audit knowledge, expertise, and auditor experience simultaneously and significantly to audit quality.
\end{abstract}

Keywords: gender, compliance pressure, audit knowledge, expertise, auditor experience, audit quality.

\section{PENDAHULUAN}

Pemerintah harus melakukan reformasi dalam segala aspek pengelolaan keuangan daerah, untuk mewujudkan good governance di lingkungan pemerintahan daerah. Salah satu langkah yang harus dilakukan pemerintah daerah adalah melakukan reformasi audit baik internal maupun eksternal dalam penyelenggaraan pemerintahan. Auditing diartikan sebagai suatu proses sistematis untuk memperoleh serta mengevaluasi bukti secara objektif mengenai informasi atau peristiwa-peristiwa ekonomi dan menentukan tingkat kesesuaiannya terhadap kriteria yang telah ditetapkan yang selanjutnya melaporkan hasilnya kepada para pengguna informasi atau mengkomunikasikan hasilnya kepada pihak-pihak yang berkepentingan (Boynton, 2003).

Audit eksternal adalah audit yang dilakukan oleh unit pemeriksa yang berada di luar organisasi yang diperiksa (Mardiasmo, 2002). Auditor eksternal pemerintah diimplementasikan oleh Badan Pemeriksa Keuangan (BPK), karena BPK merupakan lembaga yang independen dan merupakan supreme auditor. Sedangkan, audit internal adalah audit yang dilakukan oleh unit pemeriksa yang merupakan bagian 
dari organisasi yang diawasi (Mardiasmo, 2002). Auditor internal pemerintah diimplementasikan oleh Badan Pengawasan Keuangan dan Pembangunan (BPKP), Badan Pengawas Daerah (BAWASDA) dan Badan Pengawas Internal disetiap departemen yaitu Inspektorat Jendral (IRJEN). Pengawasan intern yang dilakukan oleh Aparat Pengawasan Intern Pemerintah (APIP) yang terdapat dalam Sistem Pengendalian Intern Pemerintah (SPIP) terdiri dari audit, review, evaluasi, pemantauan dan kegiatan pengawasan lainnya. Pengawasan bersifat membantu agar sasaran yang ditetapkan organisasi dapat tercapai, dan secara dini menghindari terjadinya penyimpangan pelaksanaan, penyalahgunaan wewenang, pemborosan dan kebocoran (Sukriah, dkk 2009).

Pengguna laporan hasil pemeriksaan yang dilakukan oleh APIP menginginkan adanya aparat pengawasan yang bersih, berwibawa, tertib dan teratur dalam menjalankan tugas dan fungsinya sesuai ketentuan dan norma yang berlaku. Norma dan ketentuan yang berlaku bagi auditor intern pemerintah terdiri dari kode etik APIP dan standar audit APIP. Kode etik dimaksudkan untuk menjaga perilaku APIP dalam melaksanakan tugasnya, sedangkan standar audit dimaksudkan untuk menjaga mutu hasil audit yang dilaksanakan APIP (Sukriah, dkk 2009).

Profesi auditor, khususnya internal auditor atau lebih sering dikenal dengan sebutan Satuan Pengawas Intern (SPI) saat ini didominasi oleh kaum adam. Komposisi antara laki-laki dan perempuan yang berprofesi menjadi auditor sangat jauh berbeda. Profesi ini sama sekali tidak bersinggungan dengan persoalan gender, karena kompetensi yang dibutuhkan untuk profesi ini pun tidak ada kaitannya dengan gender. Meskipun demikian fakta dan data yang ada, keberadaan perempuan dalam profesi ini sangat minim sekali, (Salsabila, 2011).

Penelitian Trisnaningsih (2003) dalam Salsabila (2011), menunjukkan bahwa tidak terdapat perbedaan atau kesetaraan komitmen organisasional, komitmen professional, motivasi dan kesempatan kerja antara auditor pria dan wanita, tetapi untuk kepuasan kerja, menunjukkan adanya perbedaan antara auditor pria dan wanita. Hasil penelitian yang dilakukan oleh Miranda (2008) menunjukkan bahwa tekanan ketaatan yang berupa perintah dari atasan dan keinginan klien untuk menyimpang dari standar profesional akan cenderung mentaati perintah tersebut walaupun perintah tersebut tidak tepat dan bertentangan dengan standar profesional. 
Auditor yang berpendidikan tinggi akan mempunyai pandangan yang lebih mengenai berbagai hal. Auditor akan semakin mempunyai banyak pengetahuan mengenai bidang yang digelutinya, sehingga dapat menyelesaikan berbagai masalah secara lebih mendalam. Hal ini dibuktikan dengan penelitian yang dilakukan oleh Salsabila (2011), yang menunjukkan hasil bahwa variabel pengetahuan berpengaruh terhadap kualitas kerja auditor internal. Keahlian auditor dalam menjalankan tugasnya juga perlu diperhatikan agar tidak terjadi permasalahan dalam mengungkapkan penyelewengan dan penyalahgunaan wewenang. Hal ini dibuktikan dengan penelitian yang dilakukan oleh Hasbullah (2013), yang menunjukkan hasil bahwa keahlian audit berpengaruh terhadap kualitas audit.

Pengalaman seorang auditor juga menjadi salah satu faktor yang mempengaruhi kualitas audit karena auditor yang lebih berpengalaman dapat mendeteksi adanya kecurangan-kecurangan pada laporan keuangan. Pengalaman audit ditunjukkan dengan jumlah penugasan audit yang pernah dilakukan (Gusti dan Ali, 2008 dalam Sabrina, 2011). Penelitian yang dilakukan Sembiring (n.d) menunjukkan bahwa variabel pengalaman dalam melaksanakan audit berpengaruh terhadap kualitas audit internal, sehingga semakin berpengalaman seorang auditor maka akan semakin baik kualitas audit yang dilakukannya.

Peneliti tertarik melakukan penelitian pada auditor yang bekerja di Inspektorat DIY didasari oleh opini masyarakat tentang rendahnya kualitas audit yang dilakukan oleh auditor internal pemerintah. Hal ini dibuktikan dengan masih banyaknya masyarakat yang mempertanyakan kinerja Inspektorat. Auditor internal pemerintah dinilai kerap kecolongan dengan masih banyaknya temuan BPK.

Penelitian ini bertujuan untuk mengetahui seberapa besar pengaruh variabel gender, tekanan ketaatan, pengetahuan, keahlian dan pengalaman auditor terhadap variabel kualitas audit, khususnya pada internal auditor pemerintah. Berdasarkan hal tersebut, maka peneliti melakukan penelitian mengenai pengaruh gender, tekanan ketaatan, pengetahuan, keahlian, dan pengalaman auditor terhadap kualitas audit (studi pada Inspektorat Provinsi Daerah Istimewa Yogyakarta). 


\section{TINJAUAN PUSTAKA}

\section{Kualitas Audit}

Menurut "Report of the Commitee on Basic Auditing Concepts of the American Accounting Association" (Accounting Review, vol. 47) dalam Boynton (2003: 5) memberikan definisi auditing sebagai "suatu proses sistematis untuk memperoleh serta mengevaluasi bukti secara objektif mengenai asersi-asersi kegiatan dan peristiwa ekonomi, dengan tujuan menetapkan derajat kesesuaian antara asersiasersi tersebut dengan kriteria yang telah ditetapkan sebelumnya serta penyampaian hasil-hasilnya kepada pihak-pihak yang berkepentingan". De Angelo (1981) dalam Efendy (2010) mendefinisikan audit quality (kualitas audit) sebagai probabilitas seorang auditor yang menemukan dan melaporkan tentang adanya suatu pelanggaran dalam sistem akuntansi kliennya. Probabilitas penemuan suatu pelanggaran tergantung pada kemampuan teknikal auditor dan independensi auditor tersebut.

\section{Gender}

Menurut Mulia (2004) dalam Agustianto (2013) gender adalah suatu konsep kultural yang dipakai untuk membedakan peran, perilaku, mentalitas dan karakteristik emosional antara laki-laki dan perempuan yang berkembang dalam masyarakat. Gender juga bisa diartikan sebagai suatu sifat yang dijadikan dasar untuk mengidentifikasi perbedaan antar laki-laki dan perempuan dilihat dari segi kondisi sosial budaya, nilai dan perilaku, mentalitas, dan emosi serta faktor-faktor non biologis lainnya.

\section{Tekanan Ketaatan}

Menurut Jamilah, dkk (2007) dalam Putri (2013), tekanan ketaatan merupakan kondisi seorang auditor yang dihadapkan pada sebuah dilema penerapan standar profesi auditor. Klien atau pimpinan dapat saja menekan auditor untuk melanggar standar profesi auditor. Hal ini tentunya akan menimbulkan tekanan pada diri auditor untuk menuruti atau tidak menuruti kemauan klien maupun pimpinannya. Oleh sebab itu, seorang auditor seringkali dihadapkan kepada situasi dilema penerapan standar profesi auditor dalam pengambilan keputusannya. Kekuasaan 
klien dan pemimpin menyebabkan auditor tidak independen lagi, karena ia menjadi tertekan dalam menjalankan pekerjaannya.

\section{Pengetahuan Auditor}

Menurut Brown dan Stanner (1983) dalam Santoso (2009), perbedaan pengetahuan diantara auditor akan berpengaruh terhadap cara auditor menyelesaikan sebuah pekerjaan. Lebih lanjut dijelaskan bahwa seorang auditor akan bisa menyelesaikan sebuah pekerjaan secara efektif jika didukung dengan pengetahuan yang dimilikinya. Kesalahan diartikan dengan seberapa banyak perbedaan (deviasi) antara kebijakan-kebijakan perusahaan tentang pencatatan akuntansi dengan kriteria yang telah distandarkan. Pengetahuan bisa diperoleh dari frekuensi seorang auditor melakukan pekerjaan dalam proses audit laporan keuangan seseorang yang melakukan pekerjaan sesuai dengan pengetahuan yang dimilikinya akan memberikan hasil yang lebih baik dari pada mereka yang tidak memiliki pengetahuan yang cukup memadai akan tugasnya (Salsabila, 2011).

\section{Keahlian Auditor}

Standar umum pertama mengatur persyaratan keahlian auditor dalam menjalankan profesinya. Auditor harus telah menjalani pendidikan dan pelatihan teknis yang cukup dalam praktik akuntansi dan teknik auditing menurut Mulyadi (2002) dalam Syafitri (2014). Keahlian lainnnya yang dituntut bagi auditor adalah melaksanakan audit ketaatan (compliance audit). Audit ini ditujukan untuk menguji apakah auditan telah mematuhi prosedur, aturan, dan kebijakan tertentu yang telah ditetapkan oleh organisasi. Oleh karena itu, auditor dituntut untuk memiliki keahlian memahami berbagai peraturan baik pada pemerintah pusat maupun pemerintah daerah.

\section{Pengalaman Auditor}

Pengalaman menurut Mulyadi (2002) dalam Putra (2012), seorang auditor harus mempunyai pengalaman dalam kegiatan auditnya, pendidikan formal dan pengalaman kerja dalam profesi akuntan merupakan dua hal penting dan saling melengkapi. Pemerintah mensyaratkan pengalaman kerja sekurang-kurangnya tiga 
tahun sebagai akuntan dengan reputasi baik dibidang audit bagi akuntan yang ingin memperoleh izin praktik dalam profesi akuntan publik.

\section{Pengaruh Gender terhadap Kualitas Audit}

Kaum pria biasanya tidak menggunakan seluruh informasi yang tersedia sehingga keputusan yang diambil kurang komprehensif dalam pengambilan keputusan. Lain halnya dengan wanita, mereka dalam mengolah informasi cenderung lebih teliti dengan menggunakan informasi yang lebih lengkap dan mengevaluasi kembali informasi tersebut dan tidak gampang menyerah. Kaum wanita relatif lebih efisien dibandingkan kaum pria selagi mendapat akses informasi. Selain itu, kaum wanita juga memiliki daya ingat yang lebih tajam terhadap suatu informasi baru dibandingkan kaum pria dan demikian halnya dengan kemampuan dalam mengolah informasi yang sedikit menjadi lebih tajam (Miranda, 2013). Menurut penelitian yang dilakukan oleh Salsabila (2011), secara simultan gender berpengaruh terhadap kualitas hasil kerja auditor internal. Berdasarkan penjelasan tersebut, maka dapat dibuat hipotesis sebagai berikut:

$\mathrm{H}_{1}$ : Gender berpengaruh terhadap kualitas audit.

\section{Tekanan Ketaatan terhadap Kualitas Audit}

Seorang auditor sering mengalami dilema dalam penerapan standar profesi auditor pada pengambilan keputusannya. Klien atau pimpinan dapat saja menekan auditor untuk melanggar standar profesi auditor. Hal ini tentunya akan menimbulkan tekanan pada diri auditor untuk menuruti atau tidak menuruti dari kemauan klien maupun pimpinannya. Terkadang tekanan ini dapat membuat auditor mengambil tindakan yang melanggar standar pemeriksaan yang akan berpengaruh terhadap hasil audit yang dilakukannya. Penelitian yang dilakukan oleh Ariyantini, dkk (2014) menunjukkan hasil bahwa tekanan ketaatan memiliki pengaruh terhadap kualitas audit judgment, jadi semakin tinggi tekanan ketaatan yang dialami, maka hasil audit akan semakin tidak tepat. Berdasarkan penjelasan tersebut, maka dapat dibuat hipotesis sebagai berikut:

$\mathrm{H}_{2}$ : Tekanan ketaatan berpengaruh terhadap kualitas audit. 


\section{Pengetahuan terhadap Kualitas Audit}

Auditor yang berpendidikan tinggi akan mempunyai pandangan yang lebih luas mengenai berbagai hal. Auditor akan semakin mempunyai banyak pengetahuan mengenai bidang yang digelutinya, sehingga dapat mengetahui berbagai masalah secara lebih mendalam yang akan menghasilkan kualitas audit yang baik. Selain itu, dengan ilmu pengetahuan yang cukup luas, akan memudahkan auditor dalam mengikuti perkembangan yang semakin kompleks. Analisis audit yang kompleks membutuhkan spektrum yang luas mengenai keahlian, pengetahuan dan pengalaman. Hasil penelitian Salsabila (2011), menunjukkan bahwa pengetahuan berpengaruh terhadap kualitas hasil kerja auditor internal. Berdasarkan penjelasan tersebut, maka dapat dibuat hipotesis sebagai berikut:

$\mathrm{H}_{3}$ : Pengetahuan auditor berpengaruh terhadap kualitas audit.

\section{Keahlian Auditor terhadap Kualitas Audit}

Keahlian auditor diperlukan dalam menjalankan tugas-tugas auditnya agar tidak terjadi penyalahgunaan wewenang. Auditor menggunakan keahliannya dalam pengumpulan bukti-bukti termasuk dengan judgment. Auditor internal diharapkan mempunyai keahlian tertentu agar tercipta kinerja audit yang baik. Penelitian yang dilakukan Hasbullah (2014), menunjukkan bahwa keahlian berpengaruh terhadap kualitas audit. Hal ini berarti secara keseluruhan tingkat keahlian audit yang dimiliki oleh auditor yang bekerja pada Inspektorat Pemerintah Kota Denpasar dan Inspektorat Pemerintah Kabupaten Gianyar termasuk kedalam kategori sangat tinggi. Dengan tingginya tingkat keahlian audit yang dimiliki, maka auditor Inspektorat Pemerintah Kota Denpasar dan Inspektorat Pemerintah Kabupaten Gianyar memiliki keahlian dalam melaksanakan tugas audit. Berdasarkan penjelasan tersebut, maka dapat dibuat hipotesis sebagai berikut:

$\mathrm{H}_{4}$ : Keahlian auditor berpengaruh terhadap kualitas audit.

\section{Pengalaman terhadap Kualitas Audit}

Pengalaman seorang auditor menjadi salah satu faktor yang mempengaruhi kualitas audit karena auditor yang lebih berpengalaman dapat mendeteksi adanya kecurangan-kecurangan pada laporan keuangan. Pengalaman yang dimaksudkan 
dalam hal ini yaitu pengalaman auditor dalam melakukan pemeriksaan laporan keuangan. Semakin tinggi pengalaman yang dimiliki oleh auditor maka semakin tinggi pula skeptisisme profesional auditornya, (Gusti dan Ali, 2008 dalam Sabrina, 2011). Penelitian yang dilakukan Sembiring (n.d) menunjukkan bahwa pengalaman berpengaruh terhadap kualitas audit. Hal ini berarti, semakin berpengalaman seorang auditor maka kualitas audit internal yang dihasilkan semakin baik. Berdasarkan penjelasan tersebut, maka dapat dibuat hipotesis sebagai berikut:

$\mathrm{H}_{5}$ : Pengalaman auditor berpengaruh terhadap kualitas audit.

\section{Model Penelitian}

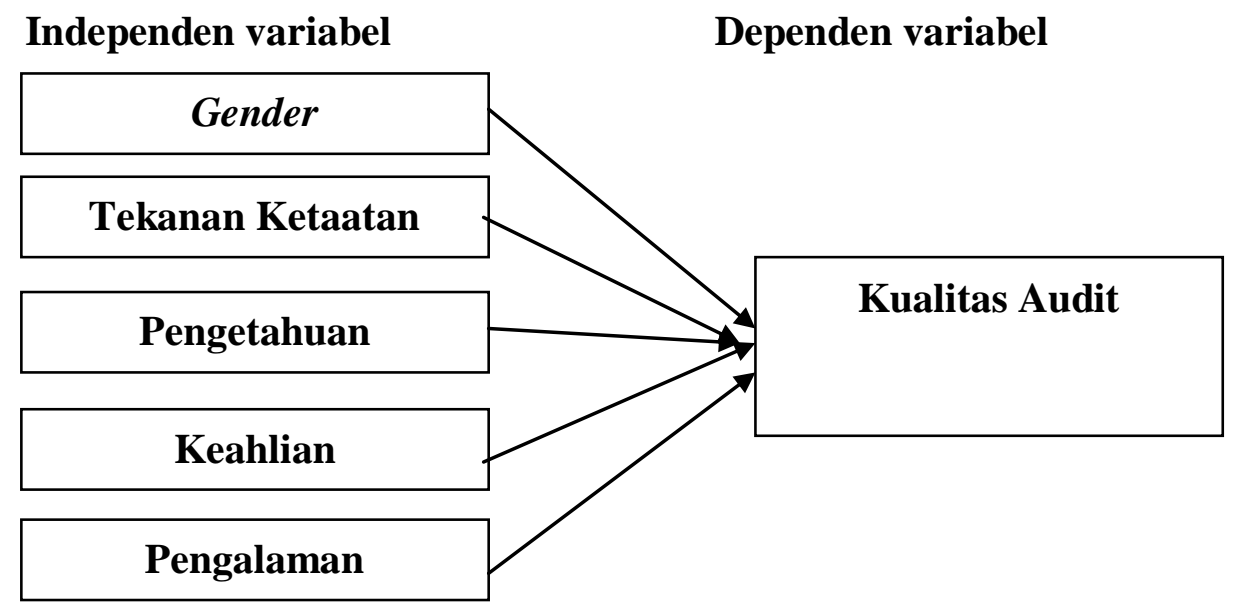

Gambar 2.1

Rerangka Penelitian

\section{METODA PENELITIAN}

\section{Populasi, Sampel, dan Teknik Pengambilan Sampel}

Populasi dalam penelitian ini adalah para auditor internal senior dan junior di Inspektorat Provinsi DIY. Prosedur pengambilan sampel pada penelitian menggunakan teknik purposive sampling yaitu pemilihan sampel berdasarkan pertimbangan atau kriteria tertentu. Adapun kriteria sampel dalam penelitian ini adalah:

a. Auditor internal yang bekerja pada Inspektorat DIY.

b. Memiliki pengalaman bekerja sebagai auditor minimal satu tahun. Dipilih mempunyai pengalaman kerja satu tahun, karena telah memiliki waktu dan 
pengalaman untuk beradaptasi serta menilai kinerja dan kondisi lingkungan kerjanya.

\section{Jenis dan Sumber Data}

Jenis data yang digunakan dalam penelitian ini adalah data primer. Data primer dalam penelitian ini berupa tanggapan para responden atas berbagai pertanyaan dalam kuesioner mengenai variabel terkait. Data diperoleh tanpa melalui perantara. Sementara sumber data dalam penelitian ini adalah para auditor internal yang bekerja di Inspektorat Provinsi DIY.

\section{Teknik Pengumpulan Data}

Pengumpulan data yang dilakukan adalah dengan menggunakan metode survei (survey method), yaitu menyebarkan daftar pertanyaan (kuesioner) yang akan diisi atau dijawab oleh responden auditor pada Inspektorat Provinsi DIY. Jawaban dari pernyataan dalam kuesioner tersebut telah ditentukan skornya berdasarkan skala Likert 5 poin.

\section{TEKNIK ANALISIS DATA}

\section{Statistik Deskriptif}

Statistik deskriptif adalah suatu alat statistik yang digunakan peneliti untuk menjelaskan dan menganalisis data dengan cara menggambarkan data yang telah terkumpul tanpa maksud untuk membuat simpulan secara umum (generalisasi).

\section{Uji Kualitas Data}

Uji validitas digunakan untuk mengukur sah atau valid tidaknya suatu kuesioner. Jika antara skor masing-masing butir pertanyaan dengan total skor mempunyai tingkat signifikansi dibawah 0,05 , maka butir pertanyaan dinyatakan valid dan sebaliknya (Ghozali, 2009:49 dalam Salsabila, 2011).

Reliabilitas adalah alat untuk mengukur suatu kuesioner yang merupakan indikator dari variabel atau konstruk. SPSS memberikan fasilitas untuk mengukur reliabilitas dengan uji statistik Cronbach Alpha. Suatu konstruk atau variabel dikatakan reliabel jika memberikan nilai Cronbach Alpha > 0,60 (Ghozali, 2009:45 dalam Salsabila, 2011). 


\section{Analisis Regresi Berganda}

\section{Uji Asumsi Klasik}

1) Uji Normalitas

Uji normalitas bertujuan untuk menguji data sampel telah memenuhi persyaratan distribusi normal atau tidak. Uji normalitas dideteksi dengan uji statistik non-parametrik One-Sample Kolmogorov-Smirnov $(K-S)$. Dasar pengambilan keputusan dari uji normalitas dengan melihat probalilitas asymp sig: (2-tailed)> tingkat kepercayaan $(\alpha)$, maka residual berdistribusi normal dan sebaliknya (Ghozali, 2006 dalam Susanti, 2012).

2) Uji Multikolinieritas

Uji ini bertujuan untuk menguji dalam model regresi ditemukan adanya korelasi yang tinggi atau sempurna antar variabel independen. Multikolinearitas dapat dilihat dari nilai tolerance (TOL) dan metoda VIF (variance inflation factor). Nilai cut off yang umum dipakai untuk menunjukkan adanya multikolinieritas adalah nilai TOL $<$ 0,10 atau sama dengan nilai VIF > 10 (Ghozali, 2009:105-106 dalam Agustianto, 2013).

3) Uji Heterokedastisitas

Uji ini bertujuan untuk menguji dalam model regresi terjadi ketidaksamaan variance dari residual satu pengamatan kepengamatan yang lain. Ada atau tidaknya gejala heterokedastisas dapat dideteksi dengan melihat grafik scatterplot, dengan analisis (Ghozali, 2009: 139 dalam Agustianto, 2013). Pengujian hipotesis dalam penelitian ini dilakukan dengan menggunakan model regresi linear berganda (multiple regressionanalysis), yaitu dilakukan melalui uji koefisien determinasi, uji statistik t dan uji statistik F.

\section{Uji Hipotesis}

1) Uji Koefisien Determinasi $\left(R^{2}\right)$

Uji ini dilakukan untuk mengukur kemampuan variabel-variabel independen, yaitu gender, tekanan ketaatan, pengetahuan, keahlian, dan pengalaman dalam menjelaskan variasi variabel dependen, yaitu kualitas audit. 


\section{2) Hasil Uji Statistik F}

Uji statistik F menguji variabel independen atau bebas yang dimasukkan dalam model mempunyai pengaruh secara bersama-sama terhadap variabel dependen atau terikat. Jika nilai $\mathrm{F}$ hitung lebih besar daripada $\mathrm{F}$ tabel, maka Ho tidak dapat diterima atau Ha diterima menyatakan bahwa semua variabel independen secara serentak dan signifikan mempengaruhi variabel dependen (Ghozali, 2009:17).

3) Hasil Uji Statistik t

Pengujian regresi secara parsial (uji t) berguna untuk menguji pengaruh dari masing-masing variabel independen terhadap variabel dependen. Ada tidaknya pengaruh dari masing-masing variabel independen terhadap variabel dependen dapat dilihat dengan membandingkan nilai probabilitas ( $p$-value) dari masing-masing variabel dengan tingkat signifikansi yang digunakan sebesar 0,05 jika p-value lebih kecil dari 0,05 maka dapat dikatakan bahwa variabel-variabel independen secara parsial mempunyai pengaruh signifikan terhadap variabel dependen.

\section{HASIL DAN PEMBAHASAN}

Statistik Deskriptif

Tabel 1

Hasil Uji Statistik Deskriptif

\begin{tabular}{|l|r|r|r|r|r|r|}
\hline & N & Minimum & Maximum & Mean & Std. Deviation & Variance \\
\hline Tekanan Ketaatan & 40 & 20.00 & 40.00 & 30.1250 & 4.81551 & 23.189 \\
\hline Pengetahuan & 40 & 37.00 & 48.00 & 40.9250 & 3.09166 & 9.558 \\
\hline Keahlian & 40 & 36.00 & 58.00 & 45.7250 & 5.11402 & 26.153 \\
\hline Pengalaman & 40 & 29.00 & 50.00 & 42.4750 & 3.74157 & 13.999 \\
\hline Kualitas Audit & 40 & 46.00 & 60.00 & 49.8500 & 4.07337 & 16.592 \\
\hline Valid N (listwise) & 40 & & & & & \\
\hline
\end{tabular}

Sumber: Data primer, diolah (2015)

Tabel 1 menjelaskan bahwa pada variabel tekanan ketaatan total jawaban minimum sebesar 20 dan total maksimum sebesar 40, dengan rata-rata total jawaban sebesar 30,1250 dan standar deviasi sebesar 4,81551. Variabel pengetahuan total jawaban minimum responden sebesar 37 dan maksimum sebesar 48, dengan rata-rata total jawaban sebesar 40,9250 dan standar deviasi sebesar 3,09166. Variabel keahlian 
total jawaban minimum sebesar 36 dan maksimum sebesar 58, dengan rata-rata total jawaban sebesar 45,7250 dan standar deviasi sebesar 5,11402. Variabel pengalaman total jawaban minimum sebesar 29 dan maksimum sebesar 50, dengan rata-rata total jawaban sebesar 42,4750 dan standar deviasi sebesar 3,74157. Variabel kualitas audit total jawaban minimum sebesar 46 dan maksimum sebesar 60 , dengan rata-rata total jawaban sebesar 49,8500 dan standar deviasi sebesar 4,07337.

\section{Uji Kualitas Data}

Hasil uji validitas menjelaskan bahwa variabel tekanan ketaatan yang diukur dengan 8 butir pertanyaan menunjukkan nilai signifikansi kurang dari 0,05. Hal ini berarti semua butir pertanyaan dinyatakan valid. Selain itu, variabel pengetahuan yang diukur dengan 10 butir pertanyaan menunjukkan nilai signifikansi kurang dari 0,05. Hal ini berarti semua butir pertanyaan dinyatakan valid.

Variabel keahlian yang diukur dengan 16 butir pertanyaan, ada 4 butir pertanyaan yang dinyatakan tidak valid yaitu pertanyaan dengan nomor 13, 14, 15, 16 karena mempunyai tingkat signifikansi lebih dari 0,05 . Hasil uji validitas juga menunjukkan bahwa variabel pengalaman yang diukur dengan 13 butir pertanyaan, ada 2 butir pertanyaan yang dinyatakan tidak valid yaitu pertanyaan dengan nomor 8 dan 13 karena mempunyai tingkat signifikansi lebih dari 0,05. Sementara itu, variabel pengetahuan dengan 12 butir pertanyaan menunjukkan nilai signifikansi kurang dari 0,05 . Hal ini berarti semua butir pertanyaan dinyatakan valid.

Berdasar hasil pengujian reliabilitas, nilai Cronbach's Alpha $>0,60$, sehingga dinyatakan reliabel. Hal ini menunjukkan bahwa semua pertanyaan yang ada dalam instrumen penelitian ini layak digunakan sebagai kuesioner untuk mengukur variabel tekanan ketaatan, pengetahuan, keahlian, pengalaman, dan kualitas audit.

\section{Analisis Regresi Berganda}

\section{Uji Asumsi Klasik}

1) Uji Normalitas

Tabel 2 menjelaskan bahwa hasil uji normalitas dengan menggunakan OneSample Kolmogorov-Smirnov menunjukkan tingkat signifikansi sebesar 0,136> 0,05. Hal ini berarti model regresi telah memenuhi asumsi normalitas. 
Tabel 2

Hasil Uji Normalitas

\begin{tabular}{|c|c|c|}
\hline Keterangan & Unstandardized Residual & Alpha \\
\hline N & 40 & \multirow{2}{*}{0,05} \\
\hline asymp.Sig. (2-tailed) & 0,135 & \\
\hline
\end{tabular}

Sumber: Data primer, diolah (2015)

\section{2) Uji Multikolinearitas}

Tabel 3 menjelaskan bahwa tidak ada masalah multikolinieritas. Hal ini dapat dilihat dari nilai variance inflation factor (VIF) $<10$ dan nilai tolerance (TOL) > 0,10 . Variabel gender memiliki nilai TOL sebesar $0,900>0,10$ dan VIF sebesar $1,111<10$. Variabel tekanan ketaatan memiliki TOL sebesar 0,911>0,10 dan VIF sebesar 1,097 < 10. Variabel pengetahuan memiliki TOL sebesar 0,644>0,10 dan VIF sebesar $1,553<10$. Variabel keahlian memiliki TOL sebesar 0,727>0,10 dan VIF sebesar 1,376 < 10. Variabel pengalaman memiliki TOL sebesar 0,835 > 0,10 dan VIF sebesar $1,197<10$.

\section{Tabel 3}

\section{Hasil Uji Multikolinearitas}

\begin{tabular}{|l|c|c|l|}
\hline \multirow{2}{*}{ Model } & \multicolumn{2}{|c|}{ Collinearity Statistics } & \multirow{2}{*}{ Keputusan } \\
\cline { 2 - 3 } & Tolerance & VIF & \\
\hline Gender & 0,900 & 1,111 & tidak terdapat mulitikolinieritas \\
\hline Tekanan Ketaatan & 0,911 & 1,097 & tidak terdapat mulitikolinieritas \\
\hline Pengetahuan & 0,644 & 1,553 & tidak terdapat mulitikolinieritas \\
\hline Keahlian & 0,727 & 1,376 & tidak terdapat mulitikolinieritas \\
\hline Pengalaman & 0,835 & 1,197 & tidak terdapat mulitikolinieritas \\
\hline
\end{tabular}

Sumber: Data primer, diolah (2015)

3) Uji Heterokedastisitas

Gambar 1 menjelaskan bahwa residual plot tidak menggambarkan pola tertentu dan tersebar secara acak di atas maupun di bawah angka nol (0) pada sumbu Y. Hal ini berarti tidak terjadi heterokedastisitas pada model persamaan regresi, sehingga model regresi layak digunakan untuk memprediksi kualitas audit berdasarkan lima variabel independennya, yaitu gender, tekanan ketaatan, pengetahuan, keahlian, dan pengalaman. 


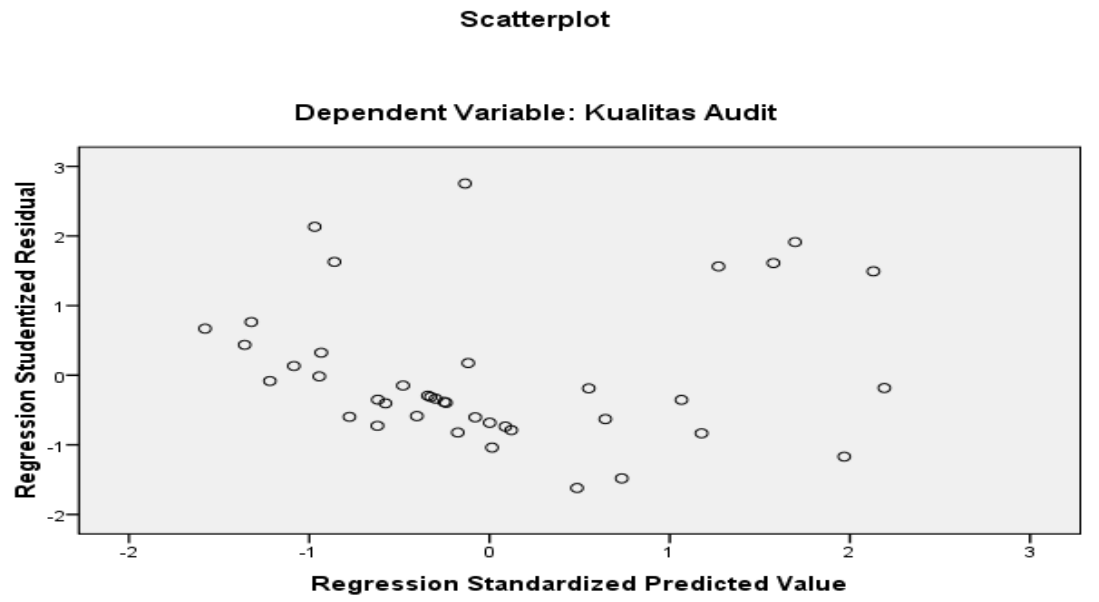

Sumber: Data primer, diolah (2015)

\section{Gambar 1 \\ Hasil Uji Heterokedastisitas}

\section{Uji Hipotesis}

1) Hasil Uji Koefisien Determinasi $\left(R^{2}\right)$

Uji ini dilakukan untuk mengukur kemampuan variabel-variabel independen, yaitu gender, tekanan ketaatan, pengetahuan, keahlian, dan pengalaman dalam menjelaskan variasi variabel dependen, yaitu kualitas audit. Hasil koefisien determinasi dapat dilihat pada kolom adjusted $R$ square, yang ditampilkan pada tabel berikut:

\section{Tabel 4}

Hasil Uji Koefisien Determinasi

\begin{tabular}{|l|r|r|}
\hline Model & $R$ Square & Adjusted $R$ Square \\
\hline 1 & 0,531 & 0,462 \\
\hline
\end{tabular}

Sumber: Data primer, diolah (2015)

Tabel 4 menjelaskan bahwa nilai koefisien adjusted $R$ square adalah sebesar 0,462 atau jika dijadikan persen adalah 46,2 \%. Artinya, variabilitas variabel kualitas audit yang dapat dijelaskan oleh variabilitas variabel gender, tekanan ketaatan, pengetahuan, keahlian, dan pengalaman adalah sebesar 46,2 \%. Sedangkan sisanya $53,8 \%$ dijelaskan oleh variabel lainnya yang tidak dimasukkan dalam model regresi. 
2) Hasil Uji Statistik F

Tabel 5

Hasil Uji Statistik F

\begin{tabular}{|l|l|r|r|r|r|r|}
\hline \multicolumn{2}{|l|}{ Model } & Sum of Squares & Df & Mean Square & F & Sig. \\
\hline \multirow{3}{*}{1} & Regression & 343.637 & 5 & 68.727 & 7.700 & $.000^{\mathrm{a}}$ \\
\cline { 2 - 5 } & Residual & 303.463 & 34 & 8.925 & & \\
\cline { 2 - 5 } & Total & 647.100 & 39 & & & \\
\hline
\end{tabular}

Sumber: Data primer, diolah (2015)

Tabel 5 menjelaskan hasil ANOVA atau hasil $\mathrm{F}$ test menunjukkan bahwa $\mathrm{F}$ hitung adalah 7,700 lebih besar dari 4 dengan tingkat signifikansi 0,000. Karena tingkat signifikansi lebih kecil dari $\alpha(0,000<0,05)$. Hal ini berarti bahwa variabel independen gender, tekanan ketaatan, pengetahuan, keahlian, dan pengalaman secara bersama-sama atau secara simultan mempengaruhi kualitas audit.

3) Hasil Uji Statistik t

Tabel 6

Hasil Uji Statistik t

\begin{tabular}{|l|c|c|l|}
\hline \multicolumn{1}{|c|}{ Model } & Signifikansi & Alpha & \multicolumn{1}{c|}{ Keputusan } \\
\hline Gender & 0,793 & 0,05 & Hipotesis ditolak \\
\hline Tekanan Ketaatan & 0,068 & 0,05 & Hipotesis ditolak \\
\hline Pengetahuan & 0,000 & 0,05 & Hipotesis diterima \\
\hline Keahlian & 0,539 & 0,05 & Hipotesis ditolak \\
\hline Pengalaman & 0,026 & 0,05 & Hipotesis diterima \\
\hline
\end{tabular}

Sumber: Data primer, diolah (2015)

Berdasarkan hasil uji t pada tabel 6 dapat disimpulkan sebagai berikut:

1) Variabel gender tidak berpengaruh terhadap kualitas audit, hal ini dapat dilihat probabilitas signifikan untuk variabel gender sebesar 0,793>0,05 yang berarti $\mathrm{Ha}_{1}$ ditolak.

2) Variabel tekanan ketaatan tidak berpengaruh terhadap kualitas audit, hal ini dapat dilihat probabilitas signifikan untuk variabel tekanan ketaatan sebesar $0,068>0,05$ yang berarti $\mathrm{Ha}_{2}$ ditolak 
3) Variabel pengetahuan berpengaruh terhadap kualitas audit, hal ini dapat dilihat probabilitas signifikannya sebesar $0,000<0,05$ yang berarti $\mathrm{Ha}_{3}$ diterima.

4) Variabel keahlian tidak berpengaruh terhadap kualitas audit, hal ini dapat dilihat dari probabilitas signifikan untuk variabel keahlian sebesar 0,539>0,05 yang berarti $\mathrm{Ha}_{4}$ ditolak.

5) Variabel pengalaman audit berpengaruh terhadap kualitas audit, hal ini dapat dilihat probabilitas signifikannya sebesar $0,026<0,05$, yang berarti $\mathrm{Ha}_{5}$ diterima.

\section{Pengaruh Gender terhadap Kualitas Audit}

Hasil penelitian menunjukkan bahwa gender tidak berpengaruh terhadap kualitas audit. Hal ini dibuktikan dengan nilai signifikansi pada tabel 4.12 yang menunjukkan 0,793 > 0,05 yang artinya tidak ada perbedaan yang signifikan tentang kualitas audit dilihat dari sisi gender. Hal ini dapat terjadi karena auditor pria dan wanita dihadapkan pada pekerjaan yang sama sehingga mereka menentukan hasil audit berdasarkan atas profesionalisme mereka sebagai auditor. Tidak ada jaminan bahwa auditor laki-laki lebih berkualitas dibandingkan dengan auditor wanita, dan sebaliknya. Laki-laki dan wanita memiliki penilaian serta keputusan yang sama ketika menghadapi pertimbangan audit. Hasil audit seseorang tidak dipengaruhi oleh perilaku, peran, dan tingkat emosional.

Penelitian ini mendukung penelitian yang dilakukan oleh Sari (2014) menyatakan bahwa perbedaan gender antara auditor pria dan wanita dengan perbedaan karakter dan sifat yang melekat pada individu masing-masing tidak berpengaruh terhadap kinerja yang dihasilkan. Dengan demikian hipotesis kesatu $\left(\mathrm{H}_{1}\right)$ penelitian ini ditolak, yang menyatakan bahwa gender tidak berpengaruh terhadap kualitas audit.

\section{Pengaruh Tekanan Ketaatan terhadap Kualitas Audit}

Hasil penelitian menunjukkan bahwa tekanan ketaatan tidak berpengaruh terhadap kualitas audit. Hal ini dibuktikan dengan nilai signifikansi pada tabel 4.12 yang menunjukkan $0,068>0,05$. Penelitian ini tidak mendukung penelitian yang dilakukan oleh Ariyantini, dkk (2014), yang menyatakan bahwa tekanan ketaatan 
berpengaruh negatif terhadap audit judgment. Hal ini menunjukkan bahwa auditor yang menerima perintah dari atasan dan tekanan yang diterima dari atasan atau klien tidak mempengaruhi hasil audit yang dilakukan oleh auditor. Mereka tidak akan merasa tertekan untuk mengikuti perintah dari atasan dan tidak akan berperilaku menyimpang dari standar profesional. Hal ini juga menunjukkan bahwa pada kenyataannya auditor memiliki keberanian dan bersikap independen untuk tidak mentaati perintah atasan atau klien apabila instruksi yang mereka berikan tidak tepat. Auditor berani mengambil risiko akan kualitas hasil audit yang dilakukan dan tidak mengacu pada keinginan atasan ataupun kliennya dan tetap mengacu pada standar profesional audit.

Hasil ini juga menunjukkan bahwa meskipun auditor dihadapkan dalam permasalahan mengenai tekanan ketaatan, auditor akan memberikan respon yang positif dengan melakukan pekerjaan sebaik-baiknya. Tekanan ketaatan dapat mendorong dan memberikan tantangan bagi auditor untuk bekerja dengan lebih giat, aktif, dan selektif dalam melakukan penilaian suatu informasi, sehingga dapat menghasilkan kualitas audit yang baik serta berdampak positif bagi kinerja auditor. Dengan demikian hipotesis kedua $\left(\mathrm{H}_{2}\right)$ penelitian ini ditolak, yang menyatakan bahwa tekanan ketaatan tidak berpengaruh terhadap kualitas audit.

\section{Pengaruh Pengetahuan terhadap Kualitas Audi}

Hasil penelitian menunjukkan bahwa pengetahuan berpengaruh signifikan terhadap kualitas audit. Hal ini dibuktikan dengan nilai signifikansi pada tabel 4.12 yang menunjukkan $0,000<0,05$. Penelitian ini mendukung penelitian yang dilakukan oleh Salsabila (2011) yang menyatakan bahwa pengetahuan audit berpengaruh positif terhadap kualitas audit yang dihasilkan.

Pengetahuan mempunyai kontribusi yang besar terhadap kualitas hasil kerja. Seorang auditor yang memiliki pengetahuan yang tinggi akan lebih mencurahkan pengetahuannya untuk menyelesaikan sebuah pekerjaan audit. Semakin tinggi pengetahuan mengenai audit, auditor akan lebih berhati-hati dalam menyeleksi setiap temuan audit dan dapat mendeteksi risiko-risiko yang akan terjadi dalam proses audit. Dengan demikian hipotesis ketiga $\left(\mathrm{H}_{3}\right)$ penelitian ini diterima, yang menyatakan bahwa pengetahuan berpengaruh signifikan terhadap kualitas audit. 


\section{Pengaruh Keahlian terhadap Kualitas Audit}

Hasil penelitian menunjukkan bahwa keahlian tidak berpengaruh terhadap kualitas audit. Hal ini dibuktikan dengan nilai signifikansi pada tabel 4.12 yang menunjukkan 0,539>0,05. Hasil penelitian ini menolak hipotesis keempat $\left(\mathrm{H}_{4}\right)$ yang menyatakan keahlian berpengaruh terhadap kualitas audit. Hal ini kemungkinan terjadi karena tingkat independensi dan integritas pada Inspektorat Provinsi DIY masih kurang, sehingga pekerjaan yang dihasilkan belum tentu menghasilkan kualitas yang memuaskan. Pekerjaan audit akan semakin berkualitas apabila tidak melanggar independensi dan integritas. Semakin tinggi keahlian yang dimiliki auditor ternyata belum tentu mendorong meningkatnya kualitas audit yang dihasilkan. Penelitian ini tidak mendukung penelitian yang dilakukan oleh Hasbullah (2014), yang menyatakan bahwa keahlian audit yang dimiliki seorang auditor, secara positif dapat mempengaruhi kualitas audit.

\section{Pengaruh Pengalaman terhadap Kualitas Audit}

Hasil penelitian menunjukkan bahwa pengalaman berpengaruh terhadap kualitas audit. Nilai signifikansinya adalah 0,026 < 0,05. Hal ini menunjukkan bahwa pengalaman auditor berpengaruh terhadap kualitas audit yang dihasilkan, dengan demikian hipotesis kelima $\left(\mathrm{H}_{5}\right)$ diterima. Penelitian ini mendukung penelitian yang dilakukan oleh Wandita (2014) yang menyatakan bahwa pengalaman kerja sangat mempengaruhi keputusan yang akan diambil. Semakin lama auditor menekuni profesinya maka akan semakin tepat dalam mendeteksi sebuah kesalahan.

Hasil penelitian ini juga konsisten dengan hasil penelitian yang dilakukan Sembiring, (n.d), yang menyatakan semakin berpengalaman seorang auditor, maka kualitas audit yang dihasilkan semakin baik. Dengan demikian hipotesis kelima $\left(\mathrm{H}_{5}\right)$ penelitian ini diterima, yang menyatakan bahwa pengalaman berpengaruh terhadap kualitas audit.

\section{SIMPULAN, KETERBATASAN, DAN SARAN}

Penelitian ini bertujuan untuk mengetahui pengaruh gender, tekanan ketaatan, pengetahuan, keahlian, dan pengalaman auditor terhadap kualitas audit. Responden 
penelitian ini berjumlah 40 orang auditor pada Inspektorat Provinsi DIY. Berdasarkan data yang telah dikumpulkan dan pengujian yang telah dilakukan terhadap permasalahan menggunakan model regresi berganda, maka dapat diambil kesimpulan sebagai berikut:

1. Gender tidak berpengaruh terhadap kualitas audit.

2. Tekanan ketaatan tidak berpengaruh terhadap kualitas audit.

3. Pengetahuan berpengaruh terhadap kualitas audit,.

4. Keahlian tidak berpengaruh terhadap kualitas audit.

5. Pengalaman berpengaruh terhadap kualitas audit.

6. Gender, tekanan ketaatan, pengetahuan, keahlian, dan pengalaman secara simultan berpengaruh terhadap kualitas audit.

Penelitian ini memiliki sejumlah keterbatasan yang perlu diperhatikan bagi penelitian yang akan datang, yaitu sebagai berikut:

1. Penelitian ini hanya melibatkan satu institusi yaitu Inspektorat Provinsi DIY, sehingga tingkat generalisasi masih kurang, dan simpulan yang diambil mungkin hanya berlaku pada Inspektorat Provinsi DIY.

2. Masih terdapat variabel independen lain yang mempengaruhi variasi dalam variabel kualitas audit yang belum tergali dalam penelitian ini.

Berdasar hasil penelitian dan keterbatasan yang ada, maka saran yang diajukan adalah:

1. Untuk penelitian selanjutnya, dapat memperluas sampel penelitian dengan memasukkan atau menambahkan sampel dari seluruh pemerintahan pada Inspektorat Provinsi DIY.

2. Untuk penelitian selanjutnya, sebaiknya menambahkan variabel independen atau variabel moderating guna mengetahui variabel-variabel lain yang dapat mempengaruhi variabel dependen, seperti akuntabilitas, kompetensi, integritas, dan komitmen organisasi. 


\section{DAFTAR PUSTAKA}

Abu, Zulkifli. 2011. Faktor-Faktor yang Berpengaruh terhadap Kualitas Audit. Skripsi. Yogyakarta: Universitas Muhammadiyah Yogyakarta.

Agustianto, Angga. 2013. Pengaruh Profesionalisme, Pengalaman Auditor, Gender, dan Kualitas Audit terhadap Pertimbangan Tingkat Materialitas dalam Proses Pengauditan Laporan Keuangan. Skripsi. Jakarta: Universitas Islam Negeri Syarif Hidayatullah Jakarta.

Ariyantini, Kadek E., Edi Sujana, Nyoman Ari Surya Darmawan. 2014. Pengaruh Pengalaman Auditor, Tekanan Ketaatan, dan Kompleksitas Tugas terhadap Audit Judgment. e-Journal S1 Ak Universitas Pendidikan Ganesha Jurnal Akuntansi Program S1 (Volume 2 No.1 Tahun 2014).

Ayuningtyas, Harvita Y. 2012. Pengaruh Pengalaman Kerja, Independensi, Objektifitas, Integritas dan Kompetensi terhadap Kualitas Hasil Audit. Skripsi. Semarang: Universitas Diponegoro.

Boynton, William C., Raymon N. Johnson, Walter G. Kell. 2003. Modern Auditing. Edisi Tujuh. Jakarta: Penerbit Erlangga.

Ghozali, Imam. 2009. Ekonometrika: Teori, Konsep, dan Aplikasi dengan SPSS 17. Semarang: Badan Penerbit Universitas Diponegoro.

Indriantoro, Nur. 1999. Metodologi Penelitian Bisnis Untuk Akuntansi dan Manajemen. Edisi pertama. Yogyakarta: BPFE-UGM.

Kurniawati, Indah. 2011. Praktikum Pengolahan Data Elektronik. Yogyakarta: FEUAD.

Madiasmo. 2002. Akuntansi Sektor Publik. Yogyakarta: Andi Offset.

Martani, Lindawati, Zulkifli Bokiu, dan Lukman Pakaya. 2013. "Pengaruh Kecermatan Profesional dan Pengalaman Kerja terhadap Kualitas Hasil Pemeriksaan". Jurnal Universitas Negeri Gorontalo.

Miranda, Andhiny. 2008. Pengaruh Gender, Tekanan Ketaatan, Kompleksitas Tugas dan Pengalaman Auditor terhadap Audit Judgment. Skripsi. Yogyakarta: Universitas Muhammadiyah Yogyakarta.

Najib, Ayu Dewi R. 2013. Pengaruh Keahlian, Independensi, Etika terhadap Kualitas Audit. Skripsi. Makassar: Universitas Hasanuddin.

Novatiani, R. Ait. 2013. Pengaruh Kemampuan Profesional Internal Audit terhadap Efektifitas Kualitas Laporan Internal Audit. Skripsi. Bandung: Universitas Widyatama Bandung. 
Peraturan Badan Pemeriksa Keuangan Republik Indonesia No. 01 Tahun 2007: Standar Pemeriksaan Keuangan Negara. Jakarta.

Peraturan Daerah Provinsi Daerah Istimewa Yogyakarta Nomor 7 Tahun 2008 tentang Organisasi dan Tata Kerja Inspektorat pasal 4 dan 5. Yogyakarta.

Peraturan Gubernur Daerah Istimewa Yogyakarta Nomor 51 Tahun 2008 tentang Rincian Tugas dan Fungsi Inspektorat. Yogyakarta.

Peraturan Menteri Negara Pendayagunaan Aparatur Negara Nomor PER/05/M.PAN/03/2008 tentang Standar Audit Aparat Pengawas Intern Pemerintah. Jakarta.

Peraturan Pemerintah Republik Indonesia. 2008. Peraturan Pemerintah Nomor 60 tahun 2008 tentang Sistem Pengendalian Internal Pemerintah. Jakarta

Pramadita, Septian Galeri. 2011. Pengaruh Kemampuan Profesional Auditor Internal dan Batasan Waktu Audit terhadap Kualitas Laporan Audit Internal pada PT. Dewasutratex. UNIKOM

Pratama, Noviardy A. 2014. Pengaruh Moral Reasoning dan Due Professional Care terhadap Kualitas Audit di Lingkungan Pemerintah Daerah. Skripsi. Yogyakarta: Universitas Negeri Yogyakarta.

Putra, Nugraha Agung E. 2012. Pengaruh Kompetensi, Tekanan Waktu, Pengalaman Kerja, Etika dan Independensi Auditor terhadap Kualitas Audit. Skripsi. Yogyakarta: Universitas Negeri Yogyakarta.

Putri, Pritta Amina. 2013. Pengaruh Lingkungan Etika, Pengalaman Auditor, dan Tekanan Ketaatan terhadap Kualitas Audit Judgment. Skripsi. Universitas Diponegoro.

Sabrina. 2011. Pengaruh Pengalaman, Keahlian, Situasi Audit, Etika dan Gender terhadap Ketepatan Pemberian Opini Auditor melalui Skeptisisme Profesional Auditor. Skripsi. Universitas Diponegoro.

Safitri, Dian. 2011. Analisis Pengaruh Pengalaman, Keahlian dan Pemanfaatan Teknologi Informasi terhadap Kualitas Hasil Audit Internal. Skripsi. Jakarta: Universitas Islam Negeri Syarif Hidayatullah.

Salsabila, Ainia, Hepi Prayudiawan. 2011. "Pengaruh Akuntabilitas, Pengetahuan Audit dan Gender terhadap Kualitas Hasil Kerja Auditor Internal". Jurnal Telaah \& Riset Akuntansi. Vol. 4. No. 1 Juli 2011. Hal. $155-175$.

Santoso, Yogi. 2009. Pengaruh Gender, Pengetahuan Auditor dan Pengalaman Auditor terhadap Audit Judgment. Skripsi. Yogyakarta: UMY. 
Sari, Astrina Sari. 2014. Pengaruh Akuntabilitas, Pengetahuan Audit, Gender, dan Integritas terhadap Kualitas Hasil Kerja Audit Internal. Skripsi Thesis. Riau: Universitas Islam Negeri Sultan Syarif Kasim.

Sembiring, Andi Yahya. Pengaruh Pengalaman dan Akuntabilitas terhadap Kualitas Audit Internal. Skripsi. Yogyakarta: Universitas Atma Jaya.

Sujarweni, Wiratna. 2014. Metodologi Penelitian, Lengkap, Praktis, dan Mudah Dipahami. Yogyakarta: PUSTAKABARUPRESS.

Sukriah, Ika, Akram, Biana Adha Inapty. 2009. "Pengaruh Pengalaman Kerja, Independensi, Objektifitas, Integritas dan Kompetensi terhadap Kualitas Hasil Pemeriksaan". SNA XII, Palembang.

Susanti, Hari. 2012. Pengaruh Kompetensi dan Independensi terhadap Kualitas Audit. Skripsi. Yogyakarta: Universitas Ahmad Dahlan.

Syafitri, Wiwit. 2014. "Pengaruh Keahlian, Independensi, Pengalaman Audit, dan Etika terhadap Kualitas Auditor pada Inspektorat Provinsi Kepulauan Riau" e-Jurnal Mahasiswa Universitas Maritim Raja Ali Haji Tanjungpinang.

Utami, Novita M. 2013. Pengaruh Pengalaman Kerja, Kompetensi, Independensi, Integritas, dan Etika terhadap Kualitas Audit. Skripsi. Yogyakarta: Universitas Ahmad Dahlan.

Wandita, Ni Luh Putu Tri Angga, Gede Adi Yuniarta, dan Nyoman Ari Surya Darmawan. "Pengaruh Pengetahuan, Pengalaman Kerja Audit dan Akuntabilitas terhadap Kualitas Hasil Kerja Auditor Internal" e-Journal S1 Ak Universitas Pendidikan Ganesha Jurusan Akuntansi Program S1. Volume 2 No. 1 Tahun 2014. 